This is a pre-copyedited, author-produced version of an article accepted for publication in the Industrial Law Journal following peer review. The version of record (2016) 45(2) Industrial Law Journal 144-175 is available online at: http://doi.org/10.1093/indlaw/dww005

\title{
Organisational responses to the abolition of mandatory retirement: case studies of Australian university practice
}

\author{
Alysia Blackham \\ Senior Lecturer, Melbourne Law School, University of Melbourne; \\ Affiliated Lecturer, Faculty of Law, University of Cambridge
}

The abolition of the UK default retirement age ('DRA') poses particular challenges for universities. However, it is still unclear how UK universities will respond to this change. To investigate these issues, this article considers theoretical perspectives regarding how organisations respond to change, with a particular focus on reflexive law. It then compares this literature with the results of comparative organisational case studies undertaken with six Australian universities in November 2013. Drawing on comparative analysis of labour laws in Australia and the UK, it considers the extent to which these responses may inform the future reactions of UK universities to the abolition of the DRA. 


\section{Introduction}

The removal of the national default retirement age ('DRA') in 2011 has fundamentally reshaped workplace relations in the UK. From this date, employers have had to justify any retirement age adopted as an Employer-Justified Retirement Age ('EJRA'). Given the significant legal uncertainty regarding when a retirement age will be 'justified', many employers are choosing to operate without fixed retirement ages. ${ }^{1}$ Therefore, retirement in the UK must now generally be managed on a case-by-case basis via negotiation with individual employees. These changes are particularly significant for universities, as many academic staff are likely to continue to work beyond a traditional retirement age of 65 if a DRA is not imposed. ${ }^{2}$ At the same time, UK universities do not typically have the human resource practices in place to manage an ageing academic workforce without a DRA. As a consequence, the abolition of the DRA may raise particular challenges for UK universities in relation to the performance management of older academic staff, the creation of opportunities for new generations of academics and the scope for workforce planning. ${ }^{3}$

Thus, it is timely to consider how UK universities might respond to the abolition of the DRA. To explore these issues, this article considers comparative experiences of Australian universities, which have been operating without mandatory retirement since

1 DWF, 'De-Regulation of Retirement - One Year on' (9 May 2012) $<$ http://www.dwf.co.uk/insight/legal-updates/deregulation-of-retirement-one-year-on> accessed 15 May 2012.

${ }^{2}$ Simonetta Manfredi and Lucy Vickers, 'Retirement and Age Discrimination: Managing Retirement in Higher Education' (2009) 38 Ind Law J 343, 356; see also Caroline Moughton and Simonetta Manfredi, 'Managing Flexible Retirement and Extended Working Lives: A Resource Guide' (2011) 5.

${ }^{3}$ BIS, 'Phasing out the Default Retirement Age: Government Response to Consultation' (13 January 2011) 3, 6. For further discussion of these challenges, see Alysia Blackham, 'Managing without Default Retirement in Universities: A Comparative Picture from Australia' (2015) 35 Legal Studies 502. 
the 1990s. Australian and UK universities have common roots, ${ }^{4}$ similar organisational structures and funding arrangements, and have adopted similar career structures and employment patterns for academic staff. While there are clear differences between academic institutions in the two countries, ${ }^{5}$ it is informative to consider how universities in a comparative jurisdiction have managed without mandatory retirement ages, and what lessons this comparative experience might have for UK institutions. ${ }^{6}$

This article commences with an overview of the law relating to retirement ages in the UK (Part 2), and discussion of reflexive law to provide theoretical grounding regarding how organisations respond to legal change (Part 3). It then considers how UK universities might respond to the abolition of the DRA, drawing on the results of organisational case studies undertaken with six Australian universities in November 2013 (Part 5). ${ }^{7}$ I argue that the different national legal contexts in which Australian and UK universities are operating offer the potential for dramatically different responses to the removal of mandatory retirement. Even so, the experiences of Australian universities provide telling lessons for their UK counterparts, which should be taken into account as universities review their approach to the ageing academic workforce.

\section{II.Abolition of the UK default retirement age}

Prior to 2006, UK employers choosing to implement a normal retirement age ('NRA') for their workforce were protected by legislation, with employees dismissed on the ground of retirement after reaching the NRA or age 65 being unable to claim unfair

\footnotetext{
${ }^{4}$ see, for example, Nicholas Barr, 'Higher Education in Australia and Britain: What Lessons?' (1998) 31 Australian Economic Review 179.

${ }^{5}$ for discussion of these differences at a sectoral level, see Blackham (n 3).

${ }^{6}$ A preliminary discussion of some of these issues has been reported elsewhere: see ibid.

${ }^{7}$ Some of the data from these case studies has been reported previously: see ibid.
} 
dismissal or redundancy payments. ${ }^{8}$ Protection of retirement ages was retained upon the introduction of age discrimination legislation in the UK: with the passing of the Employment Equality (Age) Regulations 2006, SI 2006/1031, an exception was made allowing for dismissal on the basis of retirement for workers at or over the age of 65 , creating a national default retirement age (the DRA) (reg 30). Employers were also able to retain a NRA lower than 65 if it could be objectively justified. Under the Regulations, employers were required to consider an employee's request to work beyond the retirement age and could only retire an employee in accordance with complicated procedural provisions. ${ }^{9}$ Kilpatrick describes the introduction of the DRA as a 'pragmatic concession to employer lobbying' in which the government 'buckl[ed] before employer pressure'. ${ }^{10}$ The introduction of a DRA was extensively criticised for placing age equality secondary to business performance. ${ }^{11}$

With the passage of the Employment Equality (Repeal of Retirement Age Provisions) Regulations 2011 (UK) SI 2011/1069 ('the 2011 Regulations'), it is no longer possible to retire an employee using the DRA. However, employers may still implement an employer-justified retirement age ('EJRA') so long as the requirement can be objectively justified as a proportionate means of achieving a legitimate aim. At the time, the removal of the DRA was promoted as a key means of extending working lives into old age, thereby supporting economic and pension sustainability, ${ }^{12}$ providing

\footnotetext{
${ }^{8}$ Employment Rights Act 1996, s 109.

${ }^{9}$ Employment Equality (Age) Regulations 2006, SI 2006/1031, reg 47, Sch 6. For further description and critique of these provisions, see Claire Kilpatrick, 'The New UK Retirement Regime, Employment Law and Pensions' (2008) 37 Ind Law J 1.

${ }_{10}^{10}$ ibid 23.

${ }^{11}$ see, for example, Matthew Flynn, 'The United Kingdom Government's "Business Case" Approach to the Regulation of Retirement' (2010) 30 Ageing and Society 421, 423; Mark Harcourt and others, 'The Effects of Anti-Age Discrimination Legislation: A Comparative Analysis' (2010) 26 IJCLLIR 447, 451. ${ }^{12}$ BIS, 'Flexible, Effective, Fair: Promoting Economic Growth through a Strong and Efficient Labour Market' (October 2011); BIS (n 3).
} 
individuals with adequate income in retirement; ${ }^{13}$ promoting social inclusion; ${ }^{14}$ and securing fairness and equality for older workers by preventing age discrimination. ${ }^{15}$ Thus, the 2011 Regulations sought to achieve two aims: first, they aimed to secure instrumental economic ends, in being used as a means of relieving pressure on pension systems and the labour market from demographic ageing; and, second, they sought to achieve intrinsic ends, in acknowledging the dignity and inherent worth of older workers. ${ }^{16}$

These aims may be undermined by significant legal uncertainty regarding when an EJRA will be 'justified'. The case of Seldon $v$ Clarkson Wright \& Jakes (A partnership) ${ }^{17}$ provides some limited clarification of the law in this area. In that case, the UK Supreme Court considered the appeal of a solicitor who claimed he was subject to direct age discrimination when compulsorily retired from the partnership at age 65 . In considering the case law of the CJEU, the UK Supreme Court categorised legitimate aims that could justify mandatory retirement as falling within two broad classes: intergenerational fairness, and dignity. ${ }^{18}$ In relation to the actual aims identified by the Employment Tribunal ('ET') in this case - ensuring associates were given the opportunity of partnership after a reasonable period; facilitating workforce planning; and limiting the need to use performance management to remove partners, thereby contributing to the firm's 'congenial and supportive culture' - the Court noted that each had been recognised by the CJEU as a legitimate social policy aim. The aims could also

\footnotetext{
${ }^{13}$ DWP, 'Fuller Working Lives: A Framework for Action' (June 2014).

${ }^{14}$ DWP, 'Building a Society for All Ages' (2009).

${ }^{15}$ HM Government, 'The Equality Strategy - Building a Fairer Britain' (December 2010).

${ }^{16}$ see further Alysia Blackham, 'Extending Working Life for Older Workers: An Empirical Legal Analysis of Age Discrimination Laws in the UK' (University of Cambridge 2014) ch 1.

${ }^{17}$ [2012] UKSC 16, [2012] 2 CMLR 50.

18 ibid [56]-[57].
} 
be related to the circumstances of the firm, making them legitimate in this particular case. ${ }^{19}$

Given there were legitimate aims capable of supporting the partnership's retirement age, the Supreme Court referred the matter back to the ET to determine whether relying on the retirement clause was a proportionate means of achieving those aims. ${ }^{20}$ In May 2013, the ET held that the partnership's retirement age of 65 was appropriate and reasonably necessary for achieving the aims of staff retention and planning for the future of the firm. ${ }^{21}$ However, the ET also noted that the position 'might have been different' if Mr. Seldon had been retired after abolition of the DRA and planned changes to the state pension age. ${ }^{22}$ Thus, employers may now struggle to prove that a retirement age is proportionate. Unsurprisingly, then, many employers (and universities in particular) appear unwilling to risk relying on fixed retirement ages. ${ }^{23}$

\section{How organisations respond to legal change}

The question, then, is what practical impact will this legal change have on UK universities, and how might universities manage an ageing workforce without mandatory retirement? There is substantial literature regarding organisational best practice for managing an ageing workforce. ${ }^{24}$ However, while we know how organisations should respond to an ageing workforce, the literature is still unclear as to

\footnotetext{
19 ibid [67].

20 ibid [68].

${ }^{21}$ The collegiality aim was not raised due to a lack of evidence: Seldon v Clarkson Wright \& Jakes [2013] UKET 1100275/2007 (14 May 2013) [8], [36].

22 ibid [92]. The ET's decision on proportionality was upheld by the EAT in May 2014: Seldon v Clarkson Wright \& Jakes [2014] UKEAT/0434/13/RN (13 May 2014).

${ }^{23}$ see, for example, Simonetta Manfredi and Lucy Vickers, 'Pensioning off the Mandatory Retirement Age: Implications for the Higher Education Sector’ (2013) 33 LS 289, 296.

${ }^{24}$ for a summary, see Blackham (n 16) ch 7.
} 
how organisations respond to legal change, and the removal of mandatory retirement in particular. ${ }^{25}$ At the same time, how organisations respond to and integrate legal change into their operations may have serious consequences for whether legislative aims are achieved. Thus, there is a need for more rigorous scrutiny of the link between law and organisational practice.

While there is limited understanding of how organisations respond to legal change, ${ }^{26}$ theories of reflexive law may cast some light on how legal change can trigger organisational responses. Drawing on systems theory, reflexive law acknowledges that legal impact is restricted and mediated by law's autopoietic nature, ${ }^{27}$ focusing instead on how legal regulation can promote and stimulate self-regulation within other systems ${ }^{28}$ via indirect control. ${ }^{29}$ Law, then, 'becomes a system for the coordination of action within and between semi-autonomous social subsystems ${ }^{30}$ and supports, rather than undermines, the self-referential structure of other systems. ${ }^{31}$

By achieving regulatory aims through 'enforced or stimulated self-regulation', reflexive law encourages organisational change through legal stimuli. ${ }^{32}$ Like law,

\footnotetext{
${ }^{25}$ That said, there has been some research on individual strategies used by Australian universities to manage an ageing workforce without mandatory retirement: where relevant, this is cited in Part 5 below. ${ }^{26}$ Lauren B Edelman, 'Legal Ambiguity and Symbolic Structures: Organizational Mediation of Civil Rights Law' (1992) 97 American Journal of Sociology 1531, 1532.

${ }^{27}$ Ralf Rogowski and Ton Wilthagen, 'Reflexive Labour Law: An Introduction' in Ralf Rogowski and Ton Wilthagen (eds), Reflexive Labour Law: Studies in Industrial Relations and Employment Regulation (Kluwer Law and Taxation Publishers 1994) 6.

28 ibid 7.

${ }^{29}$ Gunther Teubner, 'After Legal Instrumentalism? Strategic Models of Post-Regulatory Law' in Gunther Teubner (ed), Dilemmas of Law in the Welfare State (Walter de Gruyter 1986) 307.

${ }^{30}$ Gunther Teubner, 'Substantive and Reflexive Elements in Modern Law' (1983) 17 Law \& Society Review 239, 242.

${ }^{31}$ Teubner, 'After Legal Instrumentalism? Strategic Models of Post-Regulatory Law' (n 29$) 314$.

${ }^{32}$ Colm McLaughlin, 'Equal Pay, Litigation and Reflexive Regulation: The Case of the UK Local Authority Sector’ (2014) 43 Ind Law J 1, 4.
} 
organisations are seen as 'self-referential system[s] of interrelated communications', 33 which autonomously decide how open to be to their environment, and how to translate 'environmental perturbations' into their existing structure. ${ }^{34}$ Different organisations and organisational structures will be responsive to different types of regulation or 'perturbations'. Thus, while law may stimulate organisational change, organisations will integrate legal change into their existing structures in different and often diverging ways. Regulation should therefore reflexively respond to differences in organisational structure and behaviour. ${ }^{35}$

The 2011 Regulations reflect some aspects of reflexive law, attempting to tailor regulation to particular contexts and to integrate formal legal devices with selfregulation. In particular, by requiring employers to justify mandatory retirement ages, and allowing employees to challenge EJRAs in ETs, the 2011 Regulations may provide sufficient legal stimuli to encourage organisation to review and adapt their practices to minimise age discrimination. ${ }^{36}$

However, while the 2011 Regulations appear to embody a form of reflexive law, these aspects are generally unsupported by the institutional conditions necessary for their effective operation. The UK equality framework has failed to model effective reflexive regulation in practice, with few legal incentives for internal scrutiny and

\footnotetext{
${ }^{33}$ Gunther Teubner, "Company Interest: The Public Interest of the Enterprise "in Itself" in Ralf Rogowski and Ton Wilthagen (eds), Reflexive Labour Law: Studies in Industrial Relations and Employment Regulation (Kluwer Law and Taxation Publishers 1994) 24.

${ }^{34}$ ibid 25.

${ }^{35}$ Ian Ayres and John Braithwaite, Responsive Regulation: Transcending the Deregulation Debate (Oxford socio-legal studies, Oxford University Press 1992) 4.

${ }^{36}$ see similarly Charles F Sabel and Jonathan Zeitlin, 'Learning from Difference: The New Architecture of Experimentalist Governance in the EU' in Charles F Sabel and Jonathan Zeitlin (eds), Experimentalist Governance in the European Union: Towards a New Architecture (Oxford University Press 2012) 13.
} 
action in the private sector, limited information 'flows' regarding equality matters, ${ }^{37} \mathrm{a}$ significantly circumscribed public sector equality duty ('PSED'), ${ }^{38}$ no duty to consult interest groups in making equality decisions, ${ }^{39}$ and limited local expertise and capacity to deliberate effectively on equality matters. ${ }^{40}$ Therefore, while many commentators see 'signs of a model of reflexive regulation' in the Act, this is seen 'through a mirror, dimly', ${ }^{41}$ and 'reflexive' measures may fail to deliver the outcomes intended by Parliament. ${ }^{42}$

Further, where legislation is weakly or broadly worded, this will give significant scope for organisations to adopt different responses to legal change. As noted in Part 2 above, there remains significant legal uncertainty regarding when a retirement age will be justified. Thus, the law does little to define compliance in this area. ${ }^{43}$ In the face of this legal uncertainty, the interpretation of 'compliance' has been left largely to organisations themselves and, in larger organisations, personnel managers. ${ }^{44}$ Edelman argues that organisations 'mediate' the impact of equal opportunity law by collectively

\footnotetext{
${ }^{37}$ see Simon Deakin and Richard Hobbs, 'False Dawn for CSR? Shifts in Regulatory Policy and the Response of the Corporate and Financial Sectors in Britain' (2007) 15 Corporate Governance: An International Review 68, 70.

${ }^{38}$ Sandra Fredman and Sarah Spencer, 'Delivering Equality: Towards an Outcome-Focused Positive Duty - Submission to the Cabinet Office Equality Review and to the Discrimination Law Review' (June 2006) 9; Linda Dickens, 'The Road is Long: Thirty Years of Equality Legislation in Britain' (2007) 45 BJIR 463, 473; Sandra Fredman, 'The Public Sector Equality Duty' (2011) 40 Ind Law J 405; Sandra Fredman, 'Breaking the Mold: Equality as a Proactive Duty' (2012) 60 Am J Comp L 265, 266.

${ }^{39}$ see further Bob Hepple and others, Equality: A New Framework - Report of the Independent Review of the Enforcement of UK Anti-Discrimination Legislation (Hart 2000) 57-58; Bob Hepple, 'Enforcing Equality Law: Two Steps Forward and Two Steps Backwards for Reflexive Regulation' (2011) 40 Ind Law J 315, 330-32.

${ }^{40}$ McLaughlin (n 32) 24-25.

${ }^{41}$ Hepple (n 39) 334.

42 McLaughlin (n 32) 28.

${ }^{43}$ see similarly Frank Dobbin, Inventing Equal Opportunity (Princeton University Press 2011) 3.

${ }^{44}$ ibid 19. In contrast, it has also been argued that a 'compliance' approach is often the result of excessive regulation, which generates an employer 'backlash': Alain Klarsfeld and others, 'Social Regulation and Diversity Management: A Comparative Study of France, Canada and the UK' (2012) 18 European Journal of Industrial Relations 309, 310.
} 
constructing the meaning of legislative compliance. ${ }^{45}$ Given most organisational responses are never challenged in court, the 'collective response to law becomes the de facto construction of compliance' ${ }^{46}$ Therefore, while companies must conform to equal opportunity laws to gain 'legitimacy', managers negotiate the meaning of 'compliance' to preserve and maximise their managerial prerogative ${ }^{47}$ Companies are therefore likely to adopt symbolic responses to legal change (such as equality policies) that 'create a visible commitment to law' but have limited practical impact. ${ }^{48}$

In leaving the definition of 'compliance' to those being regulated, there is a risk that measures taken by employers to demonstrate 'compliance' and satisfy legal scrutiny will become divorced from the actual problem of age discrimination. In relation to sexual harassment law in the USA, Grossman identifies a 'misguided culture of compliance', where liability is measured by whether employers 'comply with judicially created prophylactic rules', rather than whether they successfully prevent harassment. ${ }^{49}$ In this context, 'employers could conceivably insulate themselves from liability entirely without making a dent in the underlying problem' ${ }^{50}$

The question, then, is how UK universities (and employers more generally) are likely to respond to the abolition of the DRA, particularly in the face of an incomplete reflexive law framework and limited definition of 'compliance', and the extent to which

\footnotetext{
${ }^{45}$ Edelman (n 26) 1532; see also Frank Dobbin and Erin L Kelly, 'How to Stop Harassment: Professional Construction of Legal Compliance in Organizations' (2007) 112 American Journal of Sociology 1203.

${ }^{46}$ Edelman (n 26) 1568.

47 ibid 1535.

48 ibid 1542; see also Linda Dickens and Mark Hall, 'Legal Regulation and the Changing Workplace' in William Brown and others (eds), The Evolution of the Modern Workplace (Cambridge University Press 2009) 349.

${ }^{49}$ Joanna L Grossman, 'The Culture of Compliance: The Final Triumph of Form over Substance in Sexual Harassment Law' (2003) 26 Harv Women's LJ 3, 3.

50 ibid.
} 
this will promote or impair the intrinsic and extrinsic goals of the 2011 Regulations.

While it is still too early to reach definitive conclusions regarding the responses of UK universities,${ }^{51}$ the comparative experiences of universities in Australia may provide some indication of organisational responses to law reform in this area.

\section{Mandatory retirement in Australia}

Compulsory retirement was abolished in Australia progressively over the 1990s and $2000 \mathrm{~s} .{ }^{52}$ Under the current legislative provisions, compulsory retirement is prohibited within Australian workplaces, including universities. ${ }^{53}$ However, discrimination is allowed where an employee is unable to carry out the 'inherent requirements' of their position due to age. ${ }^{54}$ Given the historical and contemporary similarities between Australian and UK universities, ${ }^{55}$ it is informative to consider how Australian universities have responded to the abolition of mandatory retirement, and what lessons this comparative experience might have for UK institutions. While there has been extensive commentary on age discrimination laws in Australia, ${ }^{56}$ there has been limited

\footnotetext{
${ }^{51}$ Though this will be explored in a later paper.

${ }^{52}$ Linda Rosenman and Sylvia McDonald, 'How Should Universities Respond to the Abolition of Compulsory Retirement?' (1995) 38 Australian Universities' Review 63. See, for example, Industrial Relations Reform Act 1993 (Cth), Anti-Discrimination (Amendment) Act 1994 (NSW), Abolition of Compulsory Age Retirement (Statutory Officeholders) Act 2001 (Cth), Age Discrimination Act 2004 (Cth). On the definition of 'retire', see Lorang v Mater Misericordiae Hospital [1994] NSWCA 362 (30 June 1994).

${ }^{53}$ Age Discrimination Act 2004 (Cth) s 18(2); Fair Work Act 2009 (Cth) s 351(1). While some state and territory legislation still contains mandatory retirement as an exception to the principle of age equality (see Anti-Discrimination Act 1998 (Tas) s 35; Anti-Discrimination Act (NT) s 36), the passage of the Age Discrimination Act 2004 (Cth) has likely rendered the sections irrelevant: Neil Rees and others, Australian Anti-Discrimination Law (2nd edn, Federation Press 2014) 61-62. See further Age Discrimination Act 2004 (Cth) ss 10, 12; Australian Constitution s 109.

${ }^{54}$ Age Discrimination Act 2004 (Cth) s 18(4)-(5); see also Fair Work Act 2009 (Cth) s 351(2)(b). For further on 'inherent requirements', see Qantas Airways Ltd v Christie (1998) 193 CLR 280.

${ }^{55}$ see, for example, Barr (n 4). See further Blackham (n 3).

${ }^{56}$ see, for example, Philip Taylor and others, 'Mature Age Employment: Recent Developments in Public Policy in Australia and the UK' (2000) 19 Australasian Journal on Ageing 125; Lynne Bennington and Ruth Wein, 'Anti-discrimination Legislation in Australia: Fair, Effective, Efficient or Irrelevant?' (2000) 21 International Journal of Manpower 21; Therese MacDermott, 'Challenging Age Discrimination in Australian Workplaces: From Anti-Discrimination Legislation to Industrial Regulation' (2011) 34 UNSW Law Jl 182.
} 
discussion of mandatory retirement since it was abolished. ${ }^{57}$ Thus, this research provides new insights into the operation of age discrimination laws in Australia, as well as offering lessons for the UK.

A case study methodology was selected for this research as it enabled the complexity of the employment of older academics to be studied in depth and interpreted in the organisational context. ${ }^{58}$ Case studies are a particularly useful method for exploring the dynamics of change. ${ }^{59}$ My research utilised instrumental case studies, examining each organisation for insight into the broader issues surrounding the employment of older academics, rather than focusing on the case study organisations for their own sake. ${ }^{60}$ Multiple-case studies were selected with the aim of achieving literal replication, ${ }^{61}$ and theoretical replication. ${ }^{62}$ Cases were sampled purposively to reflect different university structures that were predicted to influence universities' exposure and response to an ageing academic workforce: both established, researchintensive universities and newer, more teaching-focused universities were selected for study. A final determination and selection of cases was made based on practical considerations, including whether the university was physically accessible to the

\footnotetext{
${ }^{57}$ At the time, see Rosenman and McDonald (n 52); Frank Reid, 'Age Discrimination and Compulsory Retirement in Australia' (1989) 31 JIR 169; John McCallum, 'Australian Mandatory Retirement Challenged' (1990) 2 Journal of Aging \& Social Policy 183. This may be compared with the USA, where there has been more academic discussion in this area. The US experience will be considered in a later research project.

${ }^{58}$ Joe Feagin and others, 'Introduction: The Nature of the Case Study' in Joe Feagin and others (eds), $A$ Case for the Case Study (University of North Carolina Press 1991) 7-13; Helen Simons, Case Study Research in Practice (SAGE 2009) 23.

${ }^{59}$ Feagin and others (n 58) 12-13; Simons (n 58) 23.

${ }^{60}$ Robert Stake, 'Qualitative Case Studies' in Yvonna Lincoln and Norman Denzin (eds), Strategies of Qualitative Inquiry (3rd edn, SAGE 2008) 123.

${ }^{61}$ That is, achieving similar results across the case studies.

${ }^{62}$ That is, achieving contrasting results for anticipatable reasons, such as different organisational structures: Robert K Yin, Case Study Research: Design and Methods (5th edn, SAGE 2013) 57.
} 
researcher. ${ }^{63}$ The case study organisations included four Group of Eight (G8) ${ }^{64}$ universities and two members of the Australian Technology Network (ATN). ${ }^{65}$

The case studies included semi-structured interviews with Directors or senior members of the universities' Human Resources Units, and a documentary review of university policies, statistical data and other documents to add depth to the interview data, enrich the understanding of the organisational context, further scrutinise the culture of the organisation ${ }^{66}$ and corroborate, augment and clarify the evidence collected through the interviews. ${ }^{67}$ The case studies were complemented by qualitative expert interviews with national representatives from the National Tertiary Education Union ('NTEU'), the union for tertiary education workers in Australia. ${ }^{68}$ Eight interviews were conducted in total.

\section{Responses to the removal of mandatory retirement}

It has been projected that the removal of mandatory retirement in UK universities will have five key consequences: (1) more robust performance management, (2) a need for tailored working arrangements for older workers (in adjusting working hours, work responsibilities, ergonomic requirements and so forth, including through the use of flexible retirement), (3) the use of financial incentives to encourage academics to retire,

\footnotetext{
${ }^{63}$ Michael Quinn Patton, Qualitative Evaluation and Research Methods (2nd edn, Sage 1990) 181.

${ }^{64} \mathrm{~A}$ 'coalition of leading Australian universities', 'distinguished by depth and breadth in research': see https://go8.edu.au/page/go8-indicators.

${ }^{65}$ The Australian Technology Network 'brings together five of the most innovative and enterprising universities in the nation': see http://www.atn.edu.au/About-ATN/. Two other universities were also invited to participate in the study (a private university and a newer, teaching-focused institution), however neither responded to the researcher's communications.

${ }^{66}$ Simons (n 58) 63.

${ }^{67}$ Stake (n 60) 133; Yin (n 62) 107.

${ }^{68}$ These interviews were conducted with representatives from the NTEU's national office, who often deal with (or are at least informed about) complex industrial matters at the local level. Local NTEU representatives were not interviewed, as they were unlikely to contribute additional insights to this research.
} 
(4) a review of pension provisions and (5) the adoption of EJRAs. ${ }^{69}$ Drawing on the results of the Australian case studies, the likelihood and implications of these consequences will be considered in turn.

\section{Performance management}

The case studies revealed that, with the abolition of mandatory retirement in universities, many academics were choosing not to retire at a traditional retirement age of 65 (G8b, G8d, ATNb). Where recorded, the percentage of academics over 65 ranged from $4.8 \%$ of academic staff (G8d) to $5.1 \%$ of academic staff (ATNa). The universities were more than happy to accommodate older academics that were performing (G8a). However, according to one respondent, some older academic staff that wanted to remain at work could be in 'denial [of their] own capacity' to do so (ATNb), potentially flagging the need for performance management.

The case study universities used performance management for older academics in two ways. First, some institutions focused on older academics' developmental and training needs, including via performance appraisals for developmental purposes and targeted skill development, including in the use of technology (ATNa, ATNb). This represents a form of targeted training and performance assistance for older academics ${ }^{70}$ and a focus on formative or developmental goals in managing performance. ${ }^{71}$ Developmental performance appraisal is directed to 'enriching attitudes, experiences,

\footnotetext{
${ }^{69}$ see further Moughton and Manfredi (n 2); Manfredi and Vickers (n 23) 296-97. See also Blackham (n $3)$.

${ }^{70}$ Peggy G Koopman-Boyden and Lesley Macdonald, 'Ageing, Work Performance and Managing Ageing Academics’ (2003) 25 J HE Policy and Management 29, 35.

${ }^{71}$ Geoff Sharrock, 'Performance Management and Cultural Difference in the Australian University' (1999) 36 Asia Pacific Journal of Human Resources 87, 87; Leanne Morris and others, 'Rhetoric and Reality: An Examination of Performance Management in Australian Universities' [2011] AIRAANZ 2011: Proceedings of the 25th Conference of the Association of Industrial Relations Academics of Australia and New Zealand 1, 3.
} 
and skills that improve the effectiveness of employees', ${ }^{72}$ and may be a useful means of extending working lives into old age. However, while evident in some institutions, developmental performance management was generally not seen as a priority for older academics in the case study organisations, though some 'positive [developmental] stuff' may arise as a result of summative or evaluative performance management (NTEU; see further below). This is consistent with previous studies, which have found that Australian universities typically focus less on developmental than on evaluative performance management. ${ }^{73}$ Thus, there was only limited focus on development performance management in the case study organisations.

Instead, and second, some institutions focused on deficiencies in older academics' performance, via summative or evaluative performance management. However, dismissal on performance grounds remained rare in the case study universities, and even dismissal during a probation period stood out from the norm (G8d, also NTEU). ${ }^{74}$ Many respondents felt this was an area that required further focus and development in their institutions (G8a, G8c, G8d, ATNa). Thus, rather than relying on more rigorous performance management to manage older workers, the case study institutions placed more focus on financial incentives to retire (see below). Thus, concerns regarding more rigorous performance management have not played out in Australia. This may reflect the limited capacity (and inclination) of Australian universities to effectively deploy performance measures. ${ }^{75}$ It is likely that a similar reluctance will be seen in the UK, where universities have traditionally lacked effective procedures for performance

\footnotetext{
72 see Wendy R Boswell and John W Boudreau, 'Separating the Developmental and Evaluative Performance Appraisal Uses’ (2002) 16 Journal of Business and Psychology 391, 392.

${ }^{73}$ see, for example, Morris and others (n 71).

${ }^{74}$ This is consistent with previous findings: see Blackham (n 3).

${ }^{75}$ see further ibid.
} 
management, particularly for academic staff. ${ }^{76}$ That said, the UK Research Excellence Framework process may mark a shift towards a quantitative assessment of academic performance, which may lead the way to more rigorous performance processes in the UK. ${ }^{77}$

\section{Tailored working arrangements}

All Australian case study universities had processes in place to accommodate flexible work arrangements for older academics ${ }^{78}$ to support changing professional and personal obligations with age. ${ }^{79}$ Universities variously also provided: paid carers' leave to look after a spouse or grandchildren (G8a, G8b, ATNa, G8d); compassionate leave in the event of death or serious injury of a grandchild (ATNb); and paid grandparents' leave, to be taken within a month of the birth of a grandchild, if the mother did not have a partner (G8a). It was also possible for some academics to 'buy out' additional annual leave: an option taken up by many older academics (ATNb). Post-retirement contracts (see below) were also used to facilitate 'bridge' employment for older academics. ${ }^{80}$

Previous studies have found that older academics in Australia want to work flexibly: in a survey of University of Queensland staff aged 54 and over, more than two thirds of staff interested in working after the age of 65 favoured flexible working arrangements in preference to full-time work. ${ }^{81}$ A different survey found that $26 \%$ of

\footnotetext{
${ }^{76}$ ibid. These issues are explored further in the discussion of 'dignity' below.

${ }^{77}$ see, for example, Chris Parr, 'Quarter of Academics Believe REF Will Lead to Redundancies' (Times Higher Education, 16 December 2014) <https://www.timeshighereducation.co.uk/news/quarter-ofacademics-believe-ref-will-lead-to-redundancies/2017586.article> accessed 4 September 2015. At the same time, the case studies indicate that the similar Excellence in Research for Australia (ERA) framework has not effected such a change.

${ }^{78}$ Koopman-Boyden and Macdonald (n 70) 35.

${ }^{79}$ Rosenman and McDonald (n 52) 64.

${ }^{80}$ see further Bernard Casey and others, 'Human Resources Strategies and the Third Age: Policies and Practices in the UK' in Institute of Personnel Management (ed), Age and Employment: Policies, Attitudes and Practice (Institute of Personnel Management 1993) 51-54; Wendy Loretto and others, 'Older Workers and Options for Flexible Work' (EOC Working Paper, 2005) 64.

${ }^{81}$ Rosenman and McDonald (n 52) 64.
} 
academic respondents would have liked to reduce their daily working hours, and $48 \%$ would have liked to reduce their weekly or fortnightly working hours, as they approached retirement. ${ }^{82}$ However, only $14 \%$ and $28 \%$ of these respondents respectively thought that they would be able to do this in practice. ${ }^{83}$ Thus, it appears that there is significant unmet demand for flexible working among older academics in Australia.

However, while academics want to work flexibly, and flexible work and downshifting were available at all case study organisations, the take up of these options by academics was limited (G8c). Flexible work arrangements were particularly rare among those with defined benefit pensions as flexible work practices directly affect pension entitlements by reducing the academic's pre-retirement income. Further, the nature of academic work meant there was significant flexibility already built into the position (G8c), making formal flexible working arrangements unnecessary. Academic managers were also unlikely to be willing to encourage their staff to take-up flexible working or reduce their responsibilities due to a dislike of 'difficult conversations' with staff members (ATNb). Finally, many academics and researchers perceived teaching and laboratory work to be inflexible; requiring physical attendance in the classroom and laboratory at specified times (G8c). Thus, flexible working was not seen as a viable option for many older academics. This finding is consistent with previous studies: while flexible work arrangements are generally available to academic staff, a 2008 study of

\footnotetext{
${ }^{82}$ Glenda Strachan and others, 'Work and Careers in Australian Universities: Report on Employee Survey' (October 2012) 57.

83 ibid.
} 
flexible working at an Australian university found that academics had increasingly less access to flexible work arrangements due to work intensification. ${ }^{84}$

Thus, while UK universities may start to introduce flexible work options for older workers, particularly in light of the extension of the right to request flexible working to all employees with 26 weeks' service, ${ }^{85}$ concerted efforts and additional reforms may be required before older academics will make use of these policies. At the same time, recent reforms to the UK Universities Superannuation Scheme ('USS') may help to facilitate flexible work in the UK context. ${ }^{86}$ From October 2011 it has been possible for older academics to take 'flexible retirement' under USS, by drawing down up to $80 \%$ of pension benefits and continuing to work with at least a $20 \%$ reduction in pay and hours. Thus, USS arrangements may be more conducive to flexible working than those under the equivalent Australian scheme.

Going beyond flexible work, some Australian case study institutions had also adopted health, wellbeing and financial education programmes for older academics, to: assist with retirement planning; ${ }^{87}$ promote understanding of pension entitlements (G8a); ensure older academics were aware of their financial options (G8a, G8d), including retirement; raise the level of fitness and health amongst staff generally $(\mathrm{ATNb})$; and focus on maintaining the health of their workforce (G8d). Thus, with the

\footnotetext{
${ }^{84}$ Fleur Sharafizad and others, 'Flexible Work Arrangements: Accessibility in a University Environment' (2011) 53 Australian Universities' Review 43, 48.

${ }^{85}$ see Employment Rights Act 1996, s 80F; Children and Families Act 2014, s 131.

${ }^{86}$ Not all higher education staff in the UK will be members of USS: new university sector academics may instead be covered by the Teachers' Pensions scheme. While the provisions of this scheme differ, the USS will be the focus of this paper, as it is the principal scheme for universities.

${ }^{87}$ Koopman-Boyden and Macdonald (n 70) 35.
} 
removal of mandatory retirement, UK universities may wish to consider the broader health and financial needs of their older staff.

\section{Financial incentives to retire}

Financial incentives to encourage older academics to retire were used by all Australian case study universities. These incentives were managed through three key measures. First, as noted in previous studies, Australian universities have conducted 'substantial rounds of voluntary redundancies', largely targeting older academics. ${ }^{88}$ According to the NTEU, 'if you're over 58, your chances of being made redundant in the next mass redundancy round ... are very, very high.' Few respondents openly acknowledged the use of redundancy to manage older academics (ATNa, G8c), though one institution did recognise that redundancies could be used to remove those who were not performing (G8a). This strategy obviously has the potential to discriminate on the basis of age. However, the universities had received few (if any) claims of age discrimination in relation to these measures.

Second, financial incentives were included in pre-retirement contracts, which allowed academics and universities to negotiate an agreed date of departure, often accompanied by additional financial recompense or phased retirement arrangements. ${ }^{89}$ In the case studies, four universities explicitly said they used pre-retirement contracts, with provision for these arrangements included in four collective agreements and three universities' policies. However, one university had consciously discontinued using preretirement contracts, as they were regarded as potentially irresponsible on both financial and ethical grounds (G8a).

\footnotetext{
${ }^{88}$ Graeme Hugo, 'Demographic Trends in Australia's Academic Workforce' (2005) 27 Journal of Higher Education Policy and Management 327, 333.

${ }^{89}$ Moughton and Manfredi (n 2) 16.
} 
Third, early retirement schemes were used to provide financial incentives for retirement. Some enterprise agreements (G8a, G8b, ATNb) and university policies (G8c) explicitly provided for voluntary early retirement schemes, including as a means of minimising involuntary redundancies (G8b). Again, few (if any) legal challenges had been received regarding the validity of the schemes. ${ }^{90}$

In addition to using financial incentives to retire, universities addressed 'lifestyle' factors associated with retirement by creating post-retirement linkages with former academics, including via the use of emeritus, honorary and mentoring positions. ${ }^{91}$ All the case study universities offered emeritus or honorary positions to (selected) retired academic staff and two institutions engaged retired academics in mentoring and coaching roles. The universities also created post-retirement linkages via discretionary re-employment of academics on fixed term or fractional postretirement contracts. ${ }^{92}$ Three case study universities used post-retirement contracts; one university was considering implementing post-retirement contracts in the future; and another two could informally negotiate post-retirement arrangements, though there was no explicit provision for such appointments. ${ }^{93}$ These arrangements recognised older academics' skills and expertise, and facilitated an 'ongoing interface' with academia for retired staff members. ${ }^{94}$ They also allowed for succession and sharing of knowledge as individuals stayed at the university in some capacity to share their knowledge and

\footnotetext{
${ }^{90}$ For a case considering a challenge to the quantum paid under an early retirement scheme (though not the validity of the scheme itself), see Campbell v The University of Adelaide [2006] SASC 92 (31 March 2006).

${ }^{91}$ Hugo (n 88) 340.

${ }^{92}$ Moughton and Manfredi (n 2) 17.

${ }^{93}$ In one of these cases (G8d), post-retirement arrangements and honorary appointments could be negotiated as part of the pre-retirement contract.

${ }^{94}$ Koopman-Boyden and Macdonald (n 70) 35.
} 
experience (G8a). Thus, these linkages had institutional benefits, and addressed some of the 'lifestyle' issues that might deter older academics from retiring (ATNb, G8a).

Like in Australia, the responses of UK universities to the removal of the DRA may focus on both financial and lifestyle incentives to encourage academics to retire. The use of these strategies may raise issues of direct or indirect age discrimination. While the case study universities had received few legal claims in this area, it is certainly foreseeable that financial 'incentives' might be challenged on this ground. The NTEU has considered challenging some university redundancy exercises for using discriminatory criteria, though this was ultimately not pursued: 'never stand between a 63 year old academic and [a] \$150,000 pay-out.'

Unlike in Australia, UK universities may justify financial payments to older academics as a proportionate means of achieving a legitimate aim. Manfredi and Vickers have noted that such payments may arguably achieve legitimate aims of facilitating workforce planning and/or opening up opportunities for younger staff. ${ }^{95}$ Indeed, financial incentives may be more effective at achieving individual justice than mandatory retirement, as they are non-compulsory, can be subject to individual negotiation, and take into account personal circumstances. ${ }^{96}$ Thus, at a personal level, financial incentives may be preferable to the adoption of an EJRA.

However, financial incentives may pose significant financial and institutional costs for universities. According to one Australian respondent, 'horrific deals are done'

\footnotetext{
${ }^{95}$ Manfredi and Vickers (n 23) 308.

96 ibid.
} 
to get academics to retire (G8c). Pre-retirement contracts essentially require academics to forgo permanency or tenure in exchange for a financial benefit (ATNa, ATNb, G8d), posing a short-term financial cost for the university, and increasing the burden on pension systems in the long-term (G8a). The use of financial incentives may also create a 'negative feedback loop', as individuals come to expect a package or financial payout, rather than leaving voluntarily (NTEU, ATNa, ATNb). Indeed, in some case study universities pre- or post-retirement contracts were coming to be seen as an entitlement, rather than a discretionary mechanism based on need (ATNa, ATNb) ${ }^{97}$

Thus, strategies and initiatives to achieve turnover in the Australian case study institutions came at a significant financial cost (ATNa). The NTEU estimates that the use of 'redundancy ... as a proxy for performance' costs between AU\$80 and $\$ 100$ million a year in redundancy payments, though 'nearly everybody who's made redundant is replaced'. This was perceived as an 'extremely expensive' and 'improper' means of achieving turnover (NTEU), which is likely to limit the funds available for core university functions such as teaching and research. Respondents also raised concerns regarding the expense of honorary arrangements, particularly in universities with limited office and laboratory space (G8c). At the time of interview, one university had approximately 7,000 honorary positions, compared with only 12,000 staff members (G8c). Providing library, email, Intranet access and office space to these honorary appointees was a significant financial and administrative burden for the university.

\footnotetext{
${ }^{97}$ Similarly, refusing a post-retirement contract to an older staff member was seen as contrary to the collegial academic environment (ATNa).
} 
Overall, then, the strategies used by Australian universities to manage older academics bring with them a financial and cultural cost, and may jeopardise core university functions. These are outcomes UK universities must work actively to avoid. Manfredi and Vickers have argued that UK universities may prefer to just assume that staff will retire at around the age of 65 , rather than adopt such an expensive form of workforce planning. ${ }^{98}$ This may be an effective course of action, and preferable to the Australian response, assuming that most staff continue to retire voluntarily.

\section{Review of pension provisions}

Removal of the DRA may promote the financial sustainability of pension schemes, as individuals can contribute for a longer period and may draw on their pension for a shorter time. ${ }^{99}$ However, the change may also prompt a review of pension provisions, particularly if age-based boundaries or limitations are included in the scheme. In the UK, the Universities Superannuation Scheme (USS) is the principal pension scheme provided by universities for their employees. The current USS provisions may provide incentives for UK academics to retire at an earlier age than their counterparts in Australia covered by UniSuper (the industry super fund for higher education and research professionals in Australia). ${ }^{100}$

More particularly, USS provides less flexibility for older academics than the Australian scheme. The USS normal pension age is 65 , though a pension can be drawn from age 55 at a lower rate. ${ }^{101}$ It is possible to continue working beyond the normal

\footnotetext{
${ }_{98}$ Manfredi and Vickers (n 23) 308.

99 see Michael Connolly and Orla Gough, 'Age Discrimination, The Default Retirement Age and Occupational Pensions: Experiences from Canada and Predictions for Britain' [2007] Web Journal of Current Legal Issues.

${ }^{100}$ Though these arrangements will be changing from 1 April 2016: see USS, 'Changes to USS' (USS, 18 August 2015) <http://www.uss.co.uk/news/Pages/ChangestoUSS.aspx > accessed 4 September 2015. ${ }^{101}$ Early retirement reductions may apply prior to the age of 65: see USS, 'Retirement' (March 2015). Further, the years of pensionable service are likely to be lower, reducing the pension entitlement.
} 
pension age to increase pension entitlements, both by increasing the number of years of pensionable service, and by benefitting from a 'late retirement factor'. ${ }^{102}$ It is also possible to make Additional Voluntary Contributions (AVC) to USS, either to purchase additional years of service, or to buy a Money Purchase AVC, which operates as a defined contribution pension. However, this is designed for contributions prior to retirement. A USS pension must be drawn before the age of 75, and USS pensions are only payable when an individual terminates their pensionable employment. ${ }^{103}$ Finally, an employee's total income (including their pension) is assessed for income tax in the UK.

In contrast, UniSuper provides far more flexibility for older workers, and provides financial incentives to continue working into old age. UniSuper offers both defined benefit and defined contribution pension products. ${ }^{104}$ Defined benefit pensions are calculated as follows:

Benefit salary (averaged over five years) $\boldsymbol{x}$ Benefit service $\boldsymbol{x}$ Lump Sum Factor

The Lump Sum Factor varies with age, ranging from $18 \%$ for those up to 40 years old, to $23 \%$ for those aged 65 and over. Thus, there is a financial incentive to remain in employment until the age of 65 , though not necessarily beyond that age. ${ }^{105}$ A lump sum

\footnotetext{
${ }^{102}$ An increase of $0.5 \%$ for each complete month between age 65 and the actual date of retirement. 103 USS, 'Retirement' (USS, 17 March 2015) $<$ http://www.uss.co.uk/SchemeGuide/FinalSalaryBenefitssection/retirement/Pages/default.aspx> accessed 21 April 2015.

${ }^{104}$ UniSuper, 'UniSuper Products' (UniSuper, 1 April 2015) <https://www.unisuper.com.au/new-tounisuper/unisuper-products> accessed 15 April 2015.

${ }^{105}$ Further, the marginal gains from remaining in employment are likely to be slim: the Lump Sum Factor is $22 \%$ at age 60 , and only increases to $23 \%$ at age 65 . See UniSuper, 'UniSuper's Defined Benefit Division Explained' (no date) 4.
} 
pension payment may generally be accessed after the age $65,{ }^{106}$ and there is no age at which a pension must be taken. It is also possible to draw on a defined benefit pension while still working, and to continue contributing to a defined contribution pension. ${ }^{107}$ Thus, there is some incentive to continue working after age 65 , to build additional pension entitlements. In Australia, pension payments are exempt from income tax after age $60,{ }^{108}$ allowing older workers to remain in employment and to draw down on taxfree pension benefits.

A review of pension entitlements in the UK may recognise the lack of flexibility under USS, and move to a model more accommodating of working into old age. This may, in turn, encourage older workers to remain in employment beyond the age of 65 , potentially compounding the challenges for universities operating without mandatory retirement. However, it is questionable whether differences in the pension frameworks in the UK and Australia will actually affect individual behaviour in practice. While some Australian case study institutions relied on pension schemes to incentivise older academics to retire (ATNa), and universities encouraged staff to be more informed about their financial entitlements and their ability to retire at an earlier age, this information was sometimes ignored, and people continued to work anyway (ATNb). Thus, academics may continue working even where they have the financial capacity to retire, and different pension systems may have limited impact on individual behaviour in practice.

\footnotetext{
106 UniSuper, 'The Deal with Accessing Your Super Early' (UniSuper, November 2014) $<$ https://www.unisuper.com.au/about-us/super-informed-enews/november-2014/the-deal-withaccessing-your-super-early> accessed 21 April 2015.

107 UniSuper, 'Transition to Retirement' (UniSuper, 20 April 2015) $<$ https://www.unisuper.com.au/planning-for-retirement/transition-to-retirement> accessed 21 April 2015.

108 see UniSuper, 'Tax and Your Pension' (UniSuper, 20 April 2015) $<$ https://www.unisuper.com.au/pensions/pension-basics/tax-and-your-pension> accessed 21 April 2015.
} 


\section{Adopting an EJRA}

Finally, some UK universities may choose to adopt an EJRA where that can be justified as a proportionate means of achieving a legitimate aim. ${ }^{109}$ The experiences of Australian universities may provide some indication as to whether retirement ages are necessary or desirable in a university context. As noted above, the Supreme Court in Seldon identified two categories of legitimate aims that may support an EJRA: intergenerational fairness; and dignity. The case studies provide some insights into whether these aims are legitimate in the Australian context and, by extrapolation, in the UK.

\section{a) Intergenerational fairness}

As noted by Lady Hale in Seldon, intergenerational fairness can mean a variety of things, depending on the context:

it can mean facilitating access to employment by young people; it can mean enabling older people to remainis opportunities to work in a particular profession fairly between the generations; it can mean promoting diversity and the interchange of ideas between younger and older workers. ${ }^{110}$

Thus, Dewhurst has described intergenerational balance as 'essentially an entirely flexible approach arguably necessitated by the economic, social and political nature of

\footnotetext{
${ }^{109}$ Early data from Manfredi and Vickers showed that around 15\% of respondent universities thought that removal of the DRA might result in the use of an EJRA, indicating that they might have been considering this option: Manfredi and Vickers (n 23) 295.

${ }^{110}$ Seldon (n 17) [55].
} 
the issues involved.' ${ }^{111}$ Indeed, as Lady Hale acknowledged in Seldon, if 'taken to extremes', intergenerational fairness could 'justify almost any retirement age.' ${ }^{112}$ To remedy this ambiguity, Vickers and Manfredi argue that 'intergenerational fairness' should be replaced by 'intergenerational solidarity'. ${ }^{113}$ However, intergenerational solidarity is also an evolving and contested idea, ${ }^{114}$ which is unlikely to lend clarity to this area of law.

The relevance of intergenerational fairness to universities was considered by the CJEU in Georgiev. ${ }^{115}$ In that case, it was held that encouraging the recruitment of younger professors might be a legitimate aim. ${ }^{116}$ However, creating opportunities for younger professors was not the only means of encouraging intergenerational balance, with the Court also considering the benefits of a 'mix of different generations of teaching staff and researchers.' ${ }^{117}$ Thus, intergenerational balance may require that universities facilitate older academics remaining in employment, at least in some cases. In sum, then, the CJEU held that retirement ages could be justified in the university context so 'far as the posts for university professors are, in general, of a limited number and open only to people who have attained the highest qualifications in the field concerned, and [where] a vacant post has to be available for a professor to be

\footnotetext{
${ }^{111}$ Elaine Dewhurst, 'Intergenerational Balance, Mandatory Retirement and Age Discrimination in Europe: How Can the ECJ Better Support National Courts in Finding a Balance between the Generations' (2013) 50 Common Market Law Review 1333, 1335.

${ }^{112}$ Seldon (n 17) [68].

${ }^{113}$ Lucy Vickers and Simonetta Manfredi, 'Age Equality and Retirement: Squaring the Circle' (2013) 42 Ind Law J 61, 67-69.

${ }^{114}$ see, for example, Alain Supiot, Homo Juridicus: On the Anthropological Function of the Law (Verso 2007) 209; Vern L Bengtson and Petrice S Oyama, 'Intergenerational Solidarity and Conflict' in María Amparo Cruz-Saco and Sergei Zelenev (eds), Intergenerational Solidarity: Strengthening Economic and Social Ties (Palgrave Macmillan 2010) 38-39, 46-47; María Amparo Cruz-Saco, 'Intergenerational Solidarity' in María Amparo Cruz-Saco and Sergei Zelenev (eds), Intergenerational Solidarity: Strengthening Economic and Social Ties (Palgrave Macmillan 2010) 11.

${ }_{115}$ Case C-250/09 Georgiev (Social Policy) [2011] 2 CMLR 7, para 45.

116 ibid para 45.

117 ibid para 46.
} 
appointed'. ${ }^{118}$ However, the national court would need to determine whether this actually reflected the circumstances of university professors before a retirement age would be justified. ${ }^{119}$ Applying these ideas to the UK, Manfredi and Vickers have argued that, while academics jobs are not 'finite', university roles 'cannot just expand to meet demand for jobs'. ${ }^{120}$ Therefore, intergenerational fairness must be seriously evaluated as a legitimate aim in this context.

The Australian case studies also provide some support for intergenerational fairness as a legitimate aim. As discussed in a previous paper, ${ }^{121}$ a number of case study institutions noted that they had experienced challenges around workplace and succession planning with an ageing academic workforce. Intergenerational fairness could be an issue in specific faculties with low turnover (such as Arts), where it was tough for younger academics to enter the system (ATNa, also ATNb). In these specific contexts, older academics could be perceived as 'occupying headcount', preventing the university from refreshing talent $(\mathrm{ATNb})$ and relegating younger academics to fixed term contracts rather than permanent posts (G8c, G8d). Thus, for some universities, concerns about a lack of intergenerational fairness were 'very much playing out' (G8d). This is backed up by statistics relating to the availability of permanent academic posts at junior levels for the university sector as a whole in Australia. ${ }^{122}$

To address this, universities focused on developing the skill sets of early career researchers, to make them more competitive in the academic job marketplace (ATNa,

\footnotetext{
118 ibid para 52.

119 ibid para 53

${ }^{120}$ Manfredi and Vickers (n 23) 303.

${ }^{121}$ see Blackham (n 3).

122 ibid.
} 
$\mathrm{ATNb}$ ) and, in one case, provided postdoctoral researchers with a guaranteed continuing role at the end of their initial contract (ATNa). ${ }^{123}$ This reflects a general focus on promoting individual employability, ${ }^{124}$ rather than an emphasis on institutional change to support younger academics. Going beyond this narrow focus, some universities adopted a more proactive approach to succession planning, conducting extensive workforce planning exercises to analyse the age profile and intentions of their workforce (ATNa, G8d) and, in one case, employing a specialist workforce planner (G8d). Universities also used pre- and post-retirement contracts to achieve some certainty as to when individuals would retire, and/or relied on pension schemes to incentivise older academics to retire (ATNa) (discussed above). In contrast to this proactive approach, other Vice-Chancellors were (anecdotally) 'opposed in principle to workforce planning', instead relying on market mechanisms to manage the composition of their workforce (NTEU).

Thus, workforce and succession planning and intergenerational fairness remained on-going issues in some case study organisations, despite specific strategies being put in place to address them. This may support intergenerational fairness as legitimate aim in the UK context. However, while some case study universities experienced challenges with providing quality employment opportunities for younger academics, other aspects of intergenerational fairness were actually enhanced by the removal of mandatory retirement ages: older academics could remain in the workforce, and could continue to contribute to the 'interchange of ideas' for a longer period. Thus, what is 'fair' between generations in this context is not self-evidently 'uncontroversial'.

\footnotetext{
${ }^{123}$ However, the university was still grappling with how these policies would be put into place and, in particular, how these continuing roles would be funded in the long term (ATNa).

${ }^{124}$ see further Tony Maltby, 'Extending Working Lives? Employability, Work Ability and Better Quality Working Lives' (2011) 10 Social Policy and Society 299.
} 
If UK universities are to rely on intergenerational fairness as an aim for supporting an EJRA, this will require a much higher level of specificity regarding what this principle means and requires.

\section{b) Dignity}

The second category of legitimate aims identified by the Supreme Court - dignity - was described by Lady Hale as 'much more controversial' than intergenerational fairness, particularly given 'the assumptions underlying these objectives look suspiciously like stereotyping' as they conflate age with capacity. ${ }^{125}$ However, rather than question the CJEU's decision that 'the avoidance of unseemly debates about capacity is capable of being a legitimate aim', ${ }^{126}$ the Supreme Court appeared reluctantly to endorse dignity as a legitimate aim. 'Dignity' is now clearly regarded as a legitimate aim in the UK context.

That said, the dignity argument is unsound and has been rejected in government policy documents. ${ }^{127}$ While mandatory retirement is arguably a less intrusive mechanism for managing declining performance of senior workers than 'degrading' personal appraisals, ${ }^{128}$ this conflates age with capacity and wrongly assumes that ageing is necessarily a process of decline and deterioration. ${ }^{129}$ Age is not a good proxy

\footnotetext{
${ }^{125}$ Seldon (n 17) [57].

126 ibid [58].

${ }^{127}$ BIS (n 3) 2; DWP, 'Employing Older Workers: An Employer's Guide to Today's Multi-Generational Workforce' (Department for Work and Pensions February 2013) 16.

${ }^{128}$ see Richard Posner, Aging and Old Age (University of Chicago Press 1995) 351; Richard Allen Epstein, Equal Opportunity or More Opportunity? The Good Thing about Discrimination (Civitas 2002) 29.

129 see further KW Schaie, 'Ageing, Theories of', International Encyclopedia of the Social and Behavioral Sciences (Elsevier Science Ltd 2001) 317, 319-20; Carroll L Estes and others, Social Theory, Social Policy and Ageing: A Critical Introduction (Open University Press 2003) 18, 29.
} 
for capability: ${ }^{130}$ older workers form a more heterogeneous group than younger workers, as people experience ageing at different rates and in different ways. ${ }^{131}$ Rather than relying on stereotypical assumptions of capability based on age, people should be treated as individuals, and have their capabilities assessed on an individual basis. Performance appraisals will not be degrading or undermine older workers' dignity unless declining capability with age is regarded as stigmatic. ${ }^{132}$ Indeed, if individual performance appraisals undermine the dignity of older workers, it is unclear why younger workers should be subjected to appraisals at the expense of their dignity. Connolly therefore argues that 'dignity' or 'collegiality' arguments are not social policy aims: 'On the contrary, the Government's view is that dignity is preserved by performance management [emphasis in original].' ${ }^{133}$

While the 'dignity' argument is flawed, it may still influence employers' practices: employers who view capability assessments as contrary to older workers' dignity and loyalty may be reluctant to introduce performance appraisals for their entire workforce. Further, a failure to use performance appraisals in the past may mean that employers lack the capacity and skills to performance manage older workers effectively. Failed capability dismissals may well lead to an increase in unfair dismissal claims by older workers. Therefore, while flawed in theory, the 'dignity' argument may continue to shape employer responses to the ageing workforce. Abandoning the argument may have significant practical consequences for individual employers.

\footnotetext{
${ }^{130}$ Sarah Harper and Sue Marcus, 'Age-Related Capacity Decline: A Review of Some Workplace Implications' [2006] Ageing Horizons 20.

${ }^{131}$ John Grimley Evans, 'Age Discrimination: Implications of the Ageing Process' in Sandra Fredman and Sarah Spencer (eds), Age as an Equality Issue: Legal and Policy Perspectives (Hart 2003) 16.

${ }^{132}$ Sandra Fredman, 'The Age of Equality' in Sandra Fredman and Sarah Spencer (eds), Age as an Equality Issue: Legal and Policy Perspectives (Hart 2003) 45.

${ }^{133}$ Michael Connolly, 'The Coalition Government and Age Discrimination' [2012] Journal of Business Law 144, 149-50.
} 
In the case studies there was a general consensus that performance management was not more common for older academic staff than their younger peers (G8a, ATNb). Indeed, one university explicitly rejected the idea that age was correlated with performance (G8b). While some older academics were 'challenging' employees and might underperform, others were good performers - just like any group of academics (G8c). Some universities recognised that performance issues could be symptomatic of age and associated health issues (G8a), and older academics were 'performance managed like anybody else' (G8b) if an issue arose. Thus, these findings are inconsistent with the dignity argument.

However, the case studies also provide evidence supporting dignity-based arguments. As noted above, performance management is rarely used in Australian universities, with Australian universities relying on redundancy as a 'proxy for performance' management (NTEU) (and, perhaps, as a proxy for mandatory retirement). The use of redundancy to address poor performance was recognised as a 'shockingly arbitrary and disempowering method to use, because you don't have any appeal rights, because nobody ever accuses you of unsatisfactory performance' (NTEU). Fixed-term post-retirement contracts also allowed declining performance to be addressed in a less confrontational way through non-renewal (G8a). Thus, universities may be using indirect methods to address performance issues associated with older workers.

Older workers could also be treated differently to their younger colleagues when performance issues arose. In some cases performance discussions triggered conversations about retirement (G8a), allowing older academics to leave the workforce 
with their dignity intact. Similarly, if older academics needed to be 'moved on' for a failure to engage with new teaching methods or research (ATNa), it was easier to encourage them to retire than to use 'more harsh ways' such as performance management (ATNa). This is unlikely to occur in a similar way for underperforming younger academics. Where performance management was used, it was regarded as being 'on occasion very, very sad ... and expensive' (G8c) and 'a little bit heartless' and 'not necessarily the nicest way to go' (G8d), compared with the 'dignified' system under a DRA (G8c). As a result, universities tried to get individuals to come to their own realisation that they were not performing, to avoid having to formally 'manage them out' (G8d). Rather than using performance management, one university frequently used occupational health and safety policies and independent medical assessments to manage and remove older academics, particularly where there were health concerns and safety issues (ATNb). Another university sought an independent external perspective by employing consultants to report on 'problem people' (G8d).

Thus, while Australian universities theoretically applied performance standards in an age-neutral way, in practice they treated older workers differently when performance issues arose. The dignity argument appears to be strongly influencing performance management practices in Australian universities, even if it has been subject to sustained academic criticism.

This, then, provides both support for the identification of dignity as a legitimate aim in the Seldon decision, and in its application to the university sector, and a critique of the Seldon judgment. By endorsing dignity as a legitimate aim, the UK Supreme Court has provided legal support for the flawed assumptions driving human resource 
practices in Australian universities (and, potentially, in the UK). This may devolve into a vicious cycle, where employers continue to avoid implementing performance management processes to preserve employees' 'dignity', thereby supporting their case for needing an EJRA. In contrast, employers with well-developed performance management systems will be unable to justify an EJRA on this ground, as performance appraisals have been implemented without impairing employees' dignity. ${ }^{134}$ Thus, the Seldon decision may encourage the atrophying of UK employers' human resource practices, and provide a disincentive for developing performance management and appraisal systems.

It may be that UK courts are less willing to tolerate workplace practices grounded in 'dignity' arguments in the future. In Seldon, the EAT found originally that there was no evidence of under-performance by partners over the age of 65 to support a 'dignity' argument. ${ }^{135}$ However, such an argument could be successful if supported by appropriate evidence. ${ }^{136}$ When referred back to the ET following the Supreme Court decision, the collegiality aim was not raised due to a lack of evidence. ${ }^{137}$ This may recognise the evidential challenges of proving that performance declines with age, and the inherent limitations of a 'dignity' argument. Thus, while the case studies show that dignity is influential in Australian universities, this may not be sufficient to justify an EJRA in the UK.

\footnotetext{
${ }^{134}$ Seldon (n 17) [61]. See also Dewhurst (n 111) 1361. This was also raised in Engel v Transports and Environment Committee of London Councils [2013] UKET 2200472/2012 (26 April 2013) [67].

${ }^{135}$ Seldon v Clarkson Wright \& Jakes [2008] UKEAT 0063_08_1912, [2009] IRLR 267 [70].

136 ibid [71].

${ }^{137}$ Seldon v Clarkson Wright \& Jakes [2013] UKET 1100275/2007 (14 May 2013) [8], [36].
} 


\section{Discussion}

While previous studies have identified strategies that might be used to manage an ageing academic workforce, ${ }^{138}$ the results of these case studies go further, illustrating the bifurcated approach of university strategies to manage ageing. While the case study universities appeared to be introducing measures to support older academics and extend working lives (particularly via developmental assessment and training, flexible working arrangements and health programmes), they were simultaneously introducing measures to encourage older academics to retire (such as financial incentives to retire, financial education and the building of post-retirement linkages). Thus, these strategies reveal an institutional ambivalence towards older academics: while the respondents had reportedly seen real benefits from employing older academics (G8a), many institutional strategies were geared to encouraging older academics to leave the workforce. Indeed, many of these strategies may be interpreted as proxies for mandatory retirement, or a work-around to avoid the legal prohibition of retirement ages. While this may reflect the letter of the law (though this is doubtful in some cases: see above and below), it does not 'embrac[e] the spirit of the legislation' and is unlikely to achieve the broad intrinsic and instrumental policy aims of the legislation. ${ }^{139}$

Indeed, these strategies may actually encourage a form of cloaked age discrimination. While the case study universities mostly saw themselves as 'age-neutral' institutions, many of these policies inadvertently (or, perhaps, intentionally) disadvantaged older workers. There is a very real risk that these practices would be

\footnotetext{
${ }^{138}$ see, for example, Simonetta Manfredi, 'Developing Good Practice in Managing Age Diversity in the Higher Education Sector: An Evidence-Based Approach' (2008); Moughton and Manfredi (n 2).

${ }^{139}$ Richard Croucher and Clare Kelliher, 'The Right to Request Flexible Working in Britain: The Law and Organisational Realities' (2005) 21 International Journal of Comparative Labour Law and Industrial Relations 503, 510 .
} 
perceived as discriminatory (and, perhaps, justifiably so). For example, the NTEU felt that pre-retirement contracts were being used to push older academics out in 'performance-related cases or redundancy'. According to the NTEU, no academic would take a pre-retirement contract willingly, unless there was some incentive or threat to do so. This raises concerns regarding how universities are using pre-retirement contracts, and the means used to 'persuade' older academics to relinquish their tenured position. The use of financial incentives and redundancy may be indirectly (or directly) discriminatory on the basis of age, which is directly counter to the aims of removing mandatory retirement.

These concerns of discrimination also applied to the use of redundancy payments. While individuals are generally willing to accept a pay out, and are unlikely to bring a legal challenge, the NTEU is now pushing to end the culture of redundancy payments in Australian universities: 'this is a bit of a scandal that's got to stop.' Institutional reliance on redundancies as a means of managing older academics may also impact negatively upon university culture, particularly where institutions pride themselves on promoting equality of employment. Older academics targeted for redundancy often (and understandably) felt embittered by the process: "people are angry and insulted about it, but having been made angry and insulted, they say, "Well, bugger it, I'll take the money." ... [T]hey're not happy, and it clearly is age discrimination.' (NTEU) This individual 'sense of outrage' can seriously affect trust in management and commitment to the institution, and undermine employee loyalty (NTEU). Targeted redundancies may seriously undermine academic integrity and a university's internal culture. Thus, rather than promoting age-neutral workplaces, the removal of mandatory retirement in Australia may have promoted new, potentially 
discriminatory means of managing an ageing academic workforce. This has serious consequences for the effectiveness of age discrimination laws in practice, and prompts a deep reconsideration of the removal of mandatory retirement.

However, the Australian experience cannot be applied unreflexively to predict what will occur in the UK. To evaluate the possible lessons of the Australian experience for UK universities, it is necessary to consider the different legal contexts of the two countries. ${ }^{140}$ In addition to the different pension arrangements in place in the UK and Australia (see above), there are three key legal differences between the two countries, which may influence organisational responses to the removal of mandatory retirement.

First, age discrimination laws in the two countries are framed in substantially different ways, which may lead to different outcomes in practice. While mandatory retirement is prohibited in Australia, retirement ages may be objectively justified in the UK (see Part 2 above). This may affect organisational responses to the legislative framework: indeed, it is arguable that the ability to justify an EJRA reflects a form of reflexive law, which may be more effective at encouraging organisational change than the straightforward prohibition of mandatory retirement in Australia. ${ }^{141}$ The reversion to (arguably) discriminatory practices in Australian universities may reflect the 'regulatory trilemma' faced by command and control regulation, with a lack of organisational response to legal change due to incongruence between law and organisational practice. ${ }^{142}$ This trilemma might be avoided in UK universities with the use of a form of reflexive law. Further, UK universities may objectively justify

\footnotetext{
${ }^{140}$ The different sectoral contexts of higher education in Australia and the UK have been considered elsewhere: see Blackham (n 3).

${ }^{141}$ Though see the discussion in Part 3 of the limitations of a reflexive law approach in this context.

${ }^{142}$ Teubner, 'After Legal Instrumentalism? Strategic Models of Post-Regulatory Law' (n 29) 309.
} 
measures that are directly or indirectly discriminatory, such as financial incentives to retire or age-based redundancies. This process of justification may prompt more considered and reflective responses to the ageing workforce, and may help to mediate some of the negative consequences of the removal of mandatory retirement in Australia.

Second, universities in the UK are subject to the public sector equality duty ('PSED'), ${ }^{143}$ which may encourage a more proactive response to the ageing workforce via the use of reflexive law. The PSED has the potential to require public sector organisations to develop their own solutions to equality issues, therefore avoiding the regulatory trilemma ${ }^{144}$ and leading to better outcomes for older workers. However, the PSED may be too weak and inadequately framed to operate as a form of reflexive law, ${ }^{145}$ and the requirement to have 'due regard' to equality issues may be 'too flimsy' to encourage organisations to integrate equality issues into their decision-making effectively. ${ }^{146}$ Further, the use of judicial review and attempts to develop settled principles to monitor and enforce the PSED may actually exacerbate the regulatory trilemma, by either encouraging 'mere procedural compliance' and 'box ticking' by public sector organisations, ${ }^{147}$ or by forcing public bodies to seek judicial determinations of whether they have complied with the PSED. ${ }^{148}$ Thus, the PSED does not represent an effective form of reflexive law, and may not be overly effective in practice at encouraging proactive organisational responses to ageing. ${ }^{149}$ The PSED may

\footnotetext{
${ }^{143}$ see Equality Act 2010, s 149.

${ }^{144}$ Fredman, 'The Public Sector Equality Duty' (n 38) 419.

145 ibid.

146 ibid.

147 ibid 420; Fredman, 'Breaking the Mold' (n 38) 276.

${ }^{148}$ Fredman, 'Breaking the Mold' (n 38) 281.

${ }^{149}$ Despite these limitations, the PSED may have had positive impacts on the behaviour of public bodies in practice: see the examples presented to the government review of the PSED, as described by Stephenson: 'Misrepresentation and Omission - an Analysis of the Review of the Public Sector Equality Duty’ (2014) 85 The Political Quarterly 75, 77.
} 
therefore not lead to substantial differences between the behaviour of UK and Australian universities.

Third, the framework of collective bargaining in Australian and UK universities is substantially different. All the Australian case study universities were regulated by negotiated enterprise agreements ${ }^{150}$ covering their workforce. These agreements included detailed provisions regulating consultation during change processes (including restructuring), performance management, redundancy, notice, and termination. Contravening an enterprise agreement is expressly prohibited by statute, ${ }^{151}$ and contraventions may be enforced via a penalty or an order for the recovery of money due and payable under the agreement. ${ }^{152}$ Thus, the enterprise agreements in place in the case study organisations provided a relatively inflexible, comparatively generous and externally enforceable framework of employee benefits and procedural entitlements. Employee entitlements under the agreements were generally well above the statutory minima (particularly in cases of redundancy), ${ }^{153}$ and there was limited scope for creative human resource management within the confines of the agreement.

In contrast, UK collective agreements are voluntary, non-legally binding instruments, unless they are incorporated into individual employment contracts. Further,

\footnotetext{
${ }^{150}$ Enterprise agreements are collective agreements made at an enterprise level between employers and employees about terms and conditions of employment. As enterprise agreements are negotiated at an institutional level, there was no general uniformity across the agreements affecting each case study university. That said, an agreement concluded at one institution could be used to influence the bargaining process at another university (NTEU).

${ }^{151}$ Fair Work Act 2009 (Cth) s 50.

152 ibid ss 50, 539, 540.

${ }^{153}$ For example, at one of the case study universities, academic staff subject to involuntary redundancy and aged 45 and over were entitled to a severance payment of 22 weeks' salary, plus three weeks' salary per completed year of continuous service, subject to a maximum payment of 82 weeks' salary. Leave entitlements also accrued from year to year under the enterprise agreements, significantly increasing the cost of redundancy pay or the quantum of a separation agreement in some cases.
} 
collective agreements for UK universities tend to relate mostly to academic pay and consultation processes. Thus, they are much narrower in scope than their Australian counterparts. Many issues are therefore regulated by university policy, rather than collective agreement. This provides more potential for flexibility in university processes. Further, university policies are not necessarily incorporated into employment contracts, and may therefore not be legally enforceable. ${ }^{154}$ It also appears that UK universities generally determine their employee benefits by reference to statutory entitlements, which may lead to a lower level of benefit than in Australian universities. ${ }^{155}$ Thus, within this weak collective framework, UK universities have greater flexibility to respond to statutory changes than their Australian counterparts. This may provide scope for more innovative solutions to the ageing workforce. Further, the financial costs of measures to encourage academic staff to leave their employment are likely to be significantly lower than in Australia.

\section{Conclusion}

Demographic ageing is likely to pose substantial challenges for employers, and universities in particular. Prior studies have posited a range of options that might be used by universities to manage an ageing academic workforce. ${ }^{156}$ Drawing on evidence from case studies of Australian universities, this article has considered the potential consequences of these strategies, and whether they are likely to be used in practice. Australian universities demonstrate a bifurcated approach to ageing workers: while

\footnotetext{
${ }^{154}$ For a summary of the case law, see Simon Deakin and Gillian S Morris, Labour Law (6th edn, Hart 2012) 293-95.

${ }^{155}$ Though provision may be above the statutory level in some cases: see, for example, Inga Achterkamp, 'Part Three: Statutory and Non-Statutory Redundancy Payments' (LSE, 9 March 2011) $<$ http://www.lse.ac.uk/intranet/staff/humanResources/changingCircumstancesMovingOn/movingOn/re dundancy/partThree.aspx $>$ accessed 15 April 2015.

${ }^{156}$ see, for example, Moughton and Manfredi (n 2); Manfredi (n 138).
} 
some strategies are consistent with best practice, and seek to encourage the extension of working lives, others arguably represent a cloaked form of age discrimination, and are contrary to the intrinsic and instrumental aims of equality legislation. The responses of Australian universities to the removal of mandatory retirement ages may be explained by the regulatory trilemma, and illustrate the limitations of command and control regulation in this context.

Unlike in Australia, UK employers may justify mandatory retirement ages as a proportionate means of achieving a legitimate aim. While the Equality Act 2010 and 2011 Regulations arguably reflect a flawed implementation of reflexive law, ${ }^{157}$ provisions allowing the justification of EJRAs and direct and indirect age discrimination, and the PSED may help to avoid the regulatory trilemma in this context. Further, a more flexible and less protective collective bargaining context may allow UK universities to develop responsive and creative solutions to replace mandatory retirement where an EJRA is not adopted. Thus, the UK may eventually see more creative and flexible responses to the ageing workforce than we have witnessed in Australia. Future research should consider whether these responses are eventuating in practice.

More generally, the case studies presented in this article illustrate how institutions mediate the impact of law on organisational processes. While Australian universities no longer impose mandatory retirement ages, the various strategies they have adopted instead are hardly within the 'spirit' of age discrimination legislation. Indeed, the use of financial incentives to encourage older academics to retire is directly contrary to the

\footnotetext{
${ }^{157}$ see further Blackham (n 16) ch 3.
} 
intrinsic and instrumental objectives of age discrimination legislation. At the same time, the universities saw themselves as operating 'above and beyond the law', and well beyond a compliance approach $(\mathrm{G} 8 \mathrm{~b})$. The universities are therefore likely to exceed their own definition of 'legislative compliance', despite not achieving or supporting the aims of legislation. This article has therefore provided some support for the systems theory critique of command and control regulation, and may support calls for equality law in the UK to be better modeled on reflexive law. Future research should consider whether the EJRA, which may be interpreted as a form of reflexive law, is encouraging organisational outcomes that are more consistent with the aims of equality law than the command and control approach in Australia.

Finally, the case studies provide some support for the intergenerational fairness and dignity aims identified by the Supreme Court in Seldon. However, while intergenerational fairness is a real concern for some of the Australian case study institutions, we need to be more precise regarding what we mean by 'intergenerational fairness' in this context. Further, acknowledging dignity as a legitimate aim may stultify organisational human resource management processes, and deter organisations from developing rigorous performance management processes. This may be an unintended and undesirable outcome of the Seldon decision.

In sum, then, the abolition of the DRA brings with it substantial risks and significant opportunities for UK employers. The eventual results and implications of these legal reforms depend ultimately on how employers respond to this new legal landscape. UK universities ultimately have three choices: adopt an EJRA, and risk legal challenge; follow the Australian example, by adopting financial incentives to encourage 
older academics to retire, and risk creating a similar 'culture of redundancy'; or develop and adopt creative and innovative solutions that support both older academics and their employing institutions to promote more productive working relationships into old age. While all three approaches could 'comply' with the 2011 Regulations and the Equality Act 2010, only the latter is likely to promote the long-term sustainability of UK higher education institutions and respond effectively to demographic ageing. 